\title{
Readability of simulated state question ballots affects voting behavior
}

\author{
KAREN B. MICHALSKI and MICHAEL N. GUILE \\ Northeastern State University, Tahlequah, Oklahoma
}

\begin{abstract}
College students $(N=102)$ were given one of two state question ballots that were equivalent in content but differed in readability. Half the participants received the original state questions on the November 1984 Oklahoma ballot (with a mean grade-reading level of 9.7). The other subjects received rewritten versions of the state questions (with a mean grade-reading level of 5.8). The group reading the revised state questions was significantly more likely to vote negatively than the group given the less readable ballot. This finding suggests the following election strategies: proponents of a state question should strive for obscure language on the ballot, while opponents of a state question should strive for simplified language.
\end{abstract}

In recent years, the public clamor for plain language in consumer contracts has caused the passage by state legislatures of statutes dealing with the readability of such documents as leases and insurance policies (Ross, 1981). A few states have passed statutes concerning state ballots. An Oregon statute directs the secretary of state to adopt minimum standards of readability for Oregon ballot titles (Karlin, 1980). In Kansas, state constitutional amendments are required to be submitted to voters in "a brief nontechnical statement expressing the intent or purpose of the proposition and the effect of a vote for and a vote against the proposition" (Karlin, 1980, p. 550). The presumption is that plain language makes it less likely that people will assent to propositions or contracts that they fail to completely understand.

Efforts to simplify language usually focus on word difficulty and sentence length because research has demonstrated that these two factors are the most important ones influencing readability (Forgan \& Mangrum, 1976). Other factors being equal, large words and long sentences make passages difficult to read, whereas small words and short sentences make passages easier to read. Formulas to determine readability commonly use word difficulty and sentence length to estimate grade-reading level (Forgan \& Mangrum, 1976). Fry's (1968, 1977) widely utilized "Graph for Estimating Readability" uses a technique based on these two factors.

The purpose of the present study was to examine the effect that readability of state questions has on simulated voting. Given that state questions are usually written by partisan lawyers, there may be a tendency to compose

\footnotetext{
A preliminary report based on this research was presented at an Oklahoma Psychological Association research conference, Oklahoma City, April 1987. We thank C. Jack Denton for his technical assistance and two anonymous reviewers for comments on a draft of this article. Karen Michalski is now at the Center for Independence for the Disabled, Roanoke, VA. Reprint requests and other correspondence may be addressed to Michael Guile, Psychology Department, Northeastern State University, Tahlequah, OK 74464.
}

them in obfuscating language designed to increase the likelihood of passage. Simplification of the language of state questions, therefore, may have the opposite effect of facilitating "no" votes.

\section{METHOD}

\section{Subjects}

The participants were 102 college students recruited from psychology classes at Northeastern State University. Participation was voluntary and anonymous.

\section{Materials}

The 10 questions posed on the November 6, 1984 Oklahoma state ballot (Greiner, 1984a) were measured using Fry's Graph for Estimating Readability (Fry, 1968, 1977). The questions were found to have a mean grade-reading level of $9.7(S D=1.7)$. These questions were rewritten by the experimenters to make them more readable. The revised questions ${ }^{1}$ had a mean grade-reading level of $5.8(S D=0.4)$. Fry (1977) has stated that his graph's estimates are within 1 year of true readability.

\section{Procedure}

The subjects were equally and randomly divided into two groups. One group received the original state questions and the other group received the revised questions. Both groups were instructed to vote either for or against the questions as if the simulation were a real election. The students filled out the ballots in mass-testing classroom settings.

\section{RESULTS}

In the group given the revised state questions, 1 subject voted "yes" and "no" to State Question 573. The subject's data for this question only were eliminated from the analysis. As expected, there were more negative votes by participants given the more readable state questions. In the group reading the original (grade-level 9.7) state questions, there were 281 "yes" votes and 229 "no" votes, versus 228 "yes" votes and 281 "no" votes for the group receiving the revised (grade-level 5.8) state questions. This difference was significant $\left[\chi^{2}(1,1019)=\right.$ $10.41, p<.01]$. 
If this had been an actual election, the group receiving the original state questions would have approved Questions $570,572,573,575,576$, and 580 . The subjects given the revised state questions would have approved only Questions 572, 573, and 575.

\section{DISCUSSION}

The hypothesis that simplification of the language of state questions would decrease the likelihood of passage in a simulated voting experiment was supported. The subjects reading the simplified state questions were significantly more likely to vote negatively than were the subjects reading equivalent but less readable questions.

How do the results of this study compare with the outcome of the actual November 1984 balloting? There is a discrepancy. Oklahoma voters approved only one (Question 582) of the 10 state questions (Greiner, 1984b; Laughlin, 1984). This discrepancy probably relates to differences between the college student sample and the voting population. As young people, college students are in the age group least likely to vote (Burns \& Peltason, 1972; Glenn \& Grimes, 1968), presumably because of their low interest and involvement in politics (Fiske \& Kinder, 1981). The students may have taken their "voting" less seriously than a representative sample of voters. However, such differences between the present sample and the voting population do not address the voting results found in this study. The college students were randomly assigned to the original and simplified questions groups and a difference in voting behavior was obtained. Indeed, assuming that college students are likely to have better reading skills than the voting population in general, the difference in response to the reading level of the state questions is perhaps surprising. If anything, one would expect the differences in voting to be exacerbated in the general population, given their lesser reading skills relative to college students.

The outcome of this study suggests strategies for elections involving state questions. It implies that proponents of a state question should try to present their proposition on the ballot in as obscure language as possible in order to maximize the possibility of passage. In contrast, oppo- nents should strive for plain language in the ballot presentation of a state question to minimize the chances of passage.

\section{REFERENCES}

Burns, J. M., \& Peltason, J. W. (1972). Government by the people (8th ed.). Englewood Cliffs, NJ: Prentice-Hall.

FISKE, S. T., \& KINDER, D. R. (1981). Involvement, expertise, and schema use: Evidence from political cognition. In N. Cantor \& J. F. Kihlstrom (Eds.), Personality, cognition, and social interaction (pp. 171-190). Hillsdale, NJ: Erlbaum.

ForgAN, H. W., \& MANGRUM, C. T., II (1976). Teaching content area reading skills: A modular preservice and inservice program. Columbus, $\mathrm{OH}$ : Merrill.

FRY, E. (1968). A readability formula that saves time. Journal of Reading, 11, 513-516, 575-579.

FRY, E. (1977). Fry's readability graph: Clarifications, validity, and extension to level 17. Journal of Reading, 21, 242-252.

GlenN, N. D., \& Grimes, M. (1968). Aging, voting, and political interest. American Sociological Review, 33, 563-575.

Greiner, J. (1984a, November 4). Voters asked to consider 10 issues. The Sunday Oklahoman, p. A26.

GreINER, J. (1984b, November 10). State voters set record. Saturday Oklahoman \& Times, pp. 1-2.

KARLIN, C. J. (1980). Readability statutes: A survey and a proposed model. Kansas Law Review, 28, 531-552.

LAUGHUN, J. (1984, November 8). Issue's passage could lead to revenue hike. Tulsa World, pp. F1-F2.

Ross, S. M. (1981). On legalities and linguistics: Plain language legislation. Buffalo Law Review, 30, 317-363.

\section{NOTE}

1. Copies of both the original and the revised state questions are available from the second author on request.

(Manuscript received September 11, 1989.) 